\title{
High plasma amylin/islet amyloid polypeptide levels in patients with residual medullary thyroid carcinoma after total thyroidectomy
}

\author{
M Alevizaki $^{1,2}$, S I Grigorakis ${ }^{1}$, S Tseleni-Balafouta ${ }^{3}$, C C Alevizaki ${ }^{1}$, G Philippou ${ }^{1}$, E Anastasiou ${ }^{1}$ and \\ A Souvatzoglou ${ }^{1}$ \\ ${ }^{1} 1$ st Endocrine Section \& Diabetes Centre, ${ }^{2}$ Department of Clinical Therapeutics, Alexandra University Hospital and ${ }^{3}$ Department of Pathology, Athens \\ University School of Medicine, Athens, Greece
}

(Correspondence should be addressed to Maria Alevizaki, Endocrine Unit, Department of Clinical Therapeutics, Alexandra University Hospital, 80, Vassilissis Sofias Avenue, 11528 Athens, Greece; Email: mani@OTENET.gr)

\begin{abstract}
Objective: We have previously reported that amylin/islet amyloid polypeptide (IAPP) mRNA is detected in a substantial subset of medullary carcinomas of the thyroid (MTCs). The aim of this study was to determine if the amylin/IAPP gene is expressed as the IAPP peptide in MTC tissues.

Design and Methods: In 10 patients with a histological diagnosis of MTC and with persisting or recurrent disease (basal calcitonin levels $>250 \mathrm{pg} / \mathrm{ml}$ ), the fasting serum insulin and plasma glucose, IAPP and calcitonin levels were measured and compared with those of 18 normal control subjects matched for age and body mass index. IAPP expression was studied by immunohistochemistry in MTCs and lymph-node metastasis tissues.

Results: Seven of ten MTC patients had abnormally elevated IAPP levels. Plasma IAPP and serum insulin levels were correlated in both patients and controls, but the slope of the regression line was significantly higher for MTC patients. IAPP staining was detected in four out of 12 random MTC samples and in two out of five lymph-node metastases, using immunohistochemistry.

Conclusions: These results indicate that MTC cells express IAPP at the peptide level and that this raises the peripheral plasma levels. Further studies may reveal whether this is a feature of malignant disease.
\end{abstract}

European Journal of Endocrinology 145 585-589

\section{Introduction}

Medullary carcinoma of the thyroid (MTC) originates from the thyroid C-cells, which are part of the diffuse neuroendocrine system. The main product of this tumour and its metastases is the peptide calcitonin, which is the natural product of normal C-cells and thus is a valuable marker for screening and for assessing the efficacy of treatment for the disease (1).

The calcitonin-peptide superfamily consists of calcitonin, calcitonin-gene-related peptide (CGRP), amylin/ IAPP (islet amyloid polypeptide) and adrenomedullin (2). It was shown previously that the calcitonin/CGRP genes are expressed in practically all medullary carcinomas of the thyroid (3-6). So far, MTC tissues have been demonstrated to be effective in expressing calcitonin and CGRP peptides, which are also secreted and can be measured in plasma (7).

Although we have previously shown that the IAPP gene is expressed in a substantial subset of MTCs (8), there is no study showing that the IAPP gene transcript is translated in this tissue (7). IAPP was originally isolated from two sources: from human insulinoma, and from the islet amyloid found in the pancreas of type 2 diabetic patients $(9,10)$. It was subsequently shown that it is localised in the pancreatic beta cells, in the same secretory granules as insulin, and that it is cosecreted with insulin (11). Circulating IAPP is considered to be almost exclusively of pancreatic origin.

The aim of the present study was to determine if the amylin/IAPP gene is effectively processed to IAPP peptide in MTC, and to determine the IAPP plasma levels in patients with residual or metastatic MTC tissue (having high plasma calcitonin levels).

\section{Subjects and methods}

We studied 10 patients with MTC (five males, five females; mean age $54 \pm 11$ years, body mass index $24.2 \pm 4 \mathrm{~kg} / \mathrm{m}^{2}$ ), who had been operated on for MTC during the last 2-5 years and had persisting high calcitonin levels after radical thyroidectomy. All 
patients were under substitution treatment with thyroxine. None of the MTC patients had diabetes or chronic renal failure. These patients were compared with 18 non-diabetic control individuals (eight males, ten females) matched for age and body mass index (mean age $42 \pm 16$ years, body mass index $27.3 \pm$ $4.5 \mathrm{~kg} / \mathrm{m}^{2}$ ). Informed consent to participate in the study was obtained from both patients and controls.

Blood was collected after a $12 \mathrm{~h}$ fast for glucose, glycosylated hemoglobin (HbAlc), calcitonin, IAPP and insulin determinations. Plasma glucose was determined with the hexokinase method. Serum insulin immunoreactivity was measured by using the enzymelinked immunosorbent assay (Boehringer Mannheim, Mannheim, Germany); the intra-assay and interassay coefficients of variation were $7.8 \%$ and $6.4 \%$ respectively at $100 \mu \mathrm{U} / \mathrm{ml}$.

For IAPP measurements, blood was collected into prechilled isopropylene tubes with $1 \mathrm{ml}$ EDTA. Then, $2 \mathrm{ml}$ plasma were quickly separated and subsequently extracted with Sep-pack C-18 cartridges. IAPP levels were determined by means of a radioimmunoassay (Peninsula, Belmont, CA, USA) modified in our laboratory as described previously (12). The sensitivity of the assay was $0.63 \mathrm{pmol} / \mathrm{l}$; linearity of the standard curve between $1 \mathrm{pmol} /$ tube and $16.4 \mathrm{pmol} /$ tube was achieved. The recovery determined in plasma at $4.1 \mathrm{pmol} / \mathrm{l}$ and $16.4 \mathrm{pmol} / \mathrm{l}$ was $75 \%$ and $53.6 \%$ respectively, whilst the intra-assay variance was $10.9 \%$ at $1.2 \mathrm{pmol} / \mathrm{l}$. Data which represent the levels measured in the assay were not corrected for recoveries. Plasma calcitonin was measured by using a two-site immunoradiometric assay (ELSA hCT kit; CIS Bio International, Gif-Sur-Yvette, France; intra-assay coefficient of variation, $12 \%$; interassay coefficient of variation, $10.8 \%$ ).

The possibility that either calcitonin or CGRP might interfere with the IAPP assay was considered. The cross-reactivity of $\alpha$ CGRP and $\beta$ CGRP in our IAPP assay was $0.4 \%$ at $50 \%$ binding. No cross-reactivity with calcitonin was detected.

\section{Immunocytochemistry}

In order to verify IAPP-peptide expression in MTCs, we performed an immunocytochemistry study on formaldehyde-fixed, paraffin-embedded tissue from 12 specimens with medullary carcinoma of the thyroid and from five lymph-node metastases, corresponding to five out of these 12 carcinoma specimens, all of which were obtained from the archives of the Department of Pathology. In only one case were both plasma and tissue specimens available for IAPP-peptide evaluation. Sections $(5 \mu \mathrm{m})$ were deparaffinised and rehydrated through graded alcohols. Before further staining, slides were pretreated with avidin/biotin blocking reagent (Dako, Copenhagen, Denmark) for $20 \mathrm{~min}$ and with 3\% hydrogen peroxide for $5 \mathrm{~min}$ at room temperature.

Slides were then incubated for 20 min with normal swine serum (Dako X0901) at room temperature and with a polyclonal IAPP antibody (Biogenesis 04864989, New Fields, UK) diluted at 1:200 overnight in a moisture chamber at $4{ }^{\circ} \mathrm{C}$. Slides were further incubated with biotinated swine antirabbit immunoglobulin (Dako E0353) diluted at 1:300 for $30 \mathrm{~min}$ at room temperature. IAPP determination was performed with the streptavidin ABC complex (Dako K0377), using DAB 3'3 diaminobenzidine; Sigma D5637) as the chromogen. For negative controls, the primary antibody was omitted and was substituted by non-immune immunoglobulins of the same class. The immunohistochemical stain was considered as positive when a granular, brownish cytoplasmic product was present.

\section{Statistical analysis}

Standard statistical techniques were used: means were compared by using the Student's $t$-test, and the linear regressions (Pearson's) were calculated separately for each group. Calculations were done using the EPI 6 statistical package of the American Society of Epidemiology. The reference interval for the IAPP was based on measurements from healthy subjects and was calculated as the mean \pm 2 s.D.

\section{Results}

The means for plasma IAPP and serum insulin levels are shown in Table 1. Mean plasma IAPP levels were significantly higher in MTC patients $(P<0.05)$, whereas insulin and glucose levels did not differ between the two groups. HbA1c levels were in the normal range and did not differ between patients and controls (4.3 \pm 0.4 versus $4.1 \pm 0.4 \%$; not significant). Seven out of 10 patients with MTC had IAPP levels higher than the mean +2 s.D. of the control group.

Table 1 Comparison of biochemical and hormonal parameters between patients and controls.

\begin{tabular}{lccc}
\hline Parameter & \multicolumn{1}{c}{$\begin{array}{c}\text { Controls } \\
(n=18)\end{array}$} & $\begin{array}{c}\text { MTC } \\
(n=10)\end{array}$ & P values \\
\hline IAPP $(\mathrm{pg} / \mathrm{ml})$ & $7.0 \pm 4.3(1.6-16.2)$ & $26.1 \pm 22.3(2.0-70.0)$ & 0.03 \\
Insulin $(\mu \mathrm{lU} / \mathrm{ml})$ & $17.5 \pm 8.7(10.3-42.7)$ & $13.1 \pm 6.7(3.0-22.4)(n=8)$ & Not significant \\
Glucose $(\mathrm{mg} / \mathrm{dl})$ & $93.2 \pm 12.0(69-117)$ & $96.1 \pm 19.0(72-120)$ & Not significant \\
Calcitonin $(\mathrm{pg} / \mathrm{ml})$ & $15 \pm 5.0(15-78)$ & $6656 \pm 11888(263-33527)$ & \\
\hline
\end{tabular}

Values are means \pm S.D. (range). 


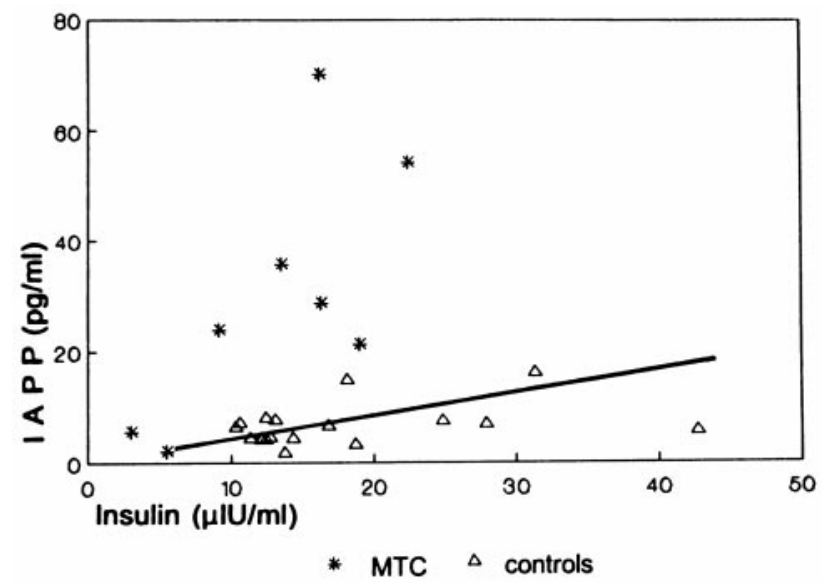

Figure 1 Correlation between basal IAPP and insulin levels in controls (triangles and regression line) and MTC patients (asterisks). (Note: insulin levels were available only in eight MTC patients.)

There was a positive linear correlation between IAPP and insulin levels in the control group $(r=+0.70, P<$ $0.01)$. A positive linear correlation between IAPP and insulin levels was found in the MTC group as well $(r=$ $+0.72, P<0.05$ ) (Fig. 1). Comparison by covariance analysis showed that the MTC group had a considerably higher regression coefficient than the control group (2.46 versus 0.341 ), and this difference was statistically significant (F slope: 12.9, degrees of freedom: 1, 23, $P<0.005)$.

Although MTC patients with higher calcitonin levels tended to have higher IAPP levels too, there was no significant correlation between the two parameters $(r=-0.06$, not significant). Interestingly, the highest IAPP levels were found in one patient in whom dedifferentiation of the tumour was assumed, as judged by the slowly decreasing calcitonin levels and the progression to death from uncontrolled disease shortly afterwards.

\section{Immunocytochemistry}

Positive reactivity for IAPP was detected in four out of 12 MTC specimens; one showed high plasma IAPP levels. A patchy pattern of distribution was observed with a focally intense cytoplasmic stain (Fig. 2), both in plasmocytoid and spindle tumour cells. Amyloid depositions in the tumour stroma exhibited only a weak focal positivity. The smallest IAPP-positive tumour had a maximal diameter of $2.8 \mathrm{~cm}$. In two cases there were lymph-node metastases which also exhibited IAPP-positive tumour cells. There were no cases of positive staining in lymph-node metastasis in the absence of staining in the primary tumour.

\section{Discussion}

Further to our previous findings regarding IAPP mRNA in MTC tissues (8), in the present study we showed (by immunocytochemistry) that the IAPP gene, somewhat like other members of the calcitonin-gene superfamily, is effectively expressed at the protein level in the largest MTC $(>2.8 \mathrm{~cm})$ tumours and in some of the metastatic lymph nodes as well. The mechanisms/factors which

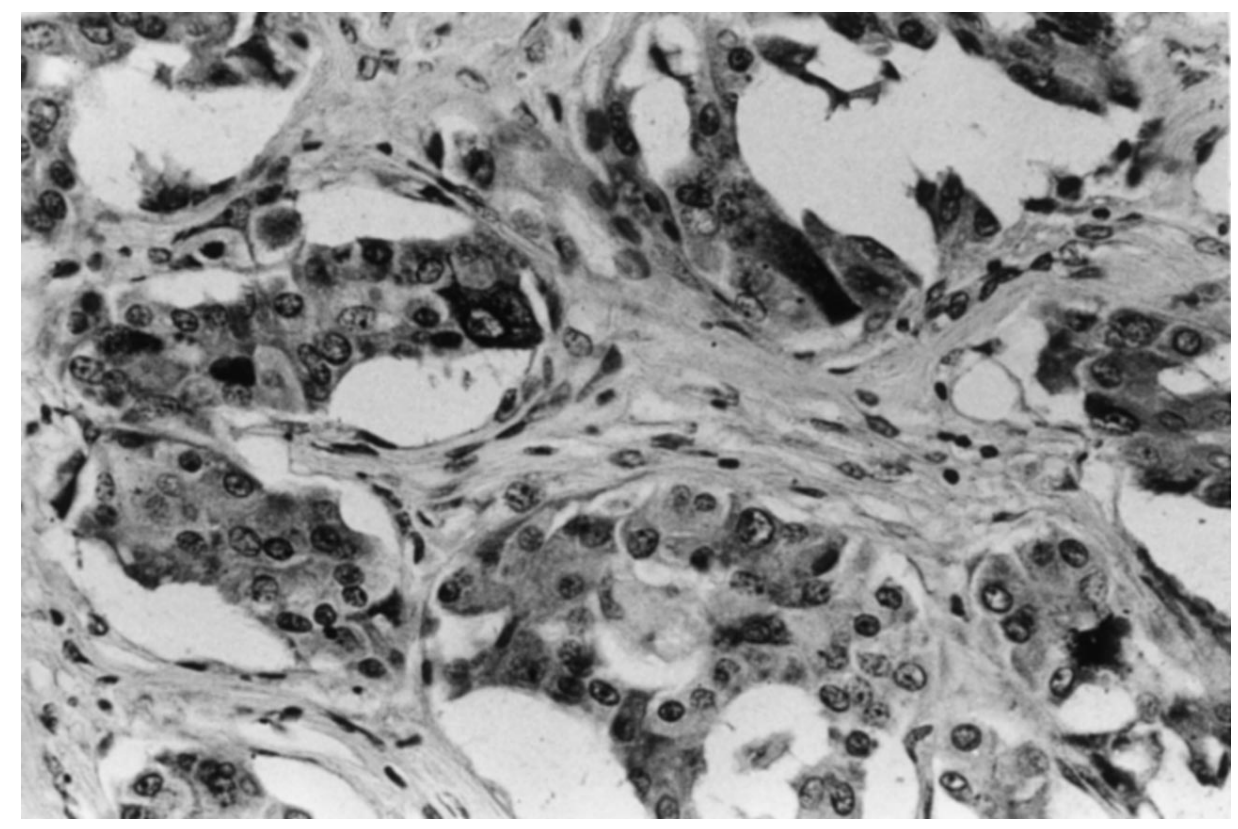

Figure 2 Immunohistochemical detection of IAPP in medullary carcinoma of the thyroid: strong focal cytoplasmic reactivity in plasmocytoid tumour cells. Avidin/biotin method; $300 \times$. 
are involved in IAPP-gene activation and IAPP-peptide processing in MTC tissues are still unknown (7). One possibility might be that unknown transcription factors are involved in the regulation of both calcitonin and IAPP genes. Interestingly, although the IAPP and insulin genes have common promoter elements, no insulin expression was found either in a series of 27 MTCs (13), or in the series of 12 MTCs previously examined by us ( 8 , unpublished observations (MA and SIG)).

We also showed that the majority $(7 / 10)$ of a group of MTC patients have elevated levels of circulating IAPP which do not inhibit pancreatic insulin secretion. Unfortunately, we did not have the chance to investigate whether there was a significant arterial/venous gradient of IAPP levels across the ectopic source or a substantial decrease in the peptide levels after tumour removal, in order definitively to show IAPP secretion, in the circulation, by MTC tissues. That there is an extrapancreatic source of IAPP production is supported by the difference in the slope of the IAPP and insulin regression line. Furthermore, the positive peptide reactivity in one-third of a random sample of MTC tissues supports the view that residual MTC cells either in the thyroid bed or in lymph nodes are probably the source of the elevated IAPP in our patients.

IAPP plasma levels in some of our patients were even higher than that reported for insulinoma, the 'home' cell type of this peptide, the IAPP levels of which are very rarely affected (14-16). It has been suggested that in those cases IAPP is probably retained in tumour cells and not secreted (16). In addition, although IAPP mRNA has been found in the gastrointestinal tract, dorsal root ganglia, and lung (17), circulating IAPP levels were not increased in patients with gastrointestinal tumours, where the peptide was detected in the respective tissues using immunohistochemistry (14). Therefore neoplastic C-cells behave differently from insulinoma cells with regard to the secretion of IAPP, maybe because of their specific differentiation.

IAPP secretion in MTC does not parallel that of calcitonin (data not shown) - a finding consistent with the results from the mRNA expression studies (8). Furthermore, we determined the highest plasma levels of IAPP in the only patient who had a de-differentiated tumour with declining calcitonin levels and a dramatic aggravation of the disease. A similar situation has been reported for CGRP production by MTC cells, where increased CGRP/low-calcitonin production has been observed in a de-differentiated MTC cell line (18). Thus, the increased ratio of IAPP and/or CGRP to calcitonin may reflect the de-differentiation of the $\mathrm{C}$ cells. Interestingly, the immunohistochemistry data showed positive staining mainly in the largest tumours, which are usually the most aggressive ones. We did not have the chance to measure plasma CGRP levels in our patients, but CGRP and IAPP mRNA levels did not seem to be related in a previous study (8).
From our data, we are unable to define the role (if one exists) of IAPP in MTC tissue. IAPP is known to inhibit stimulated insulin secretion locally in vitro through a paracrine effect in islet cells (19). Since it is known that IAPP infusion does not affect calcitonin secretion by C-cells (20), there is a possibility of an IAPP inhibitory effect on calcitonin secretion, involving an autocrine/paracrine mechanism - possibly via an interaction with insulin receptors (2).

One further question that remains is whether IAPP has a function in cell division, as it has been reported to have mitogenic effects in various cell types $(21,22)$; in vitro studies will be needed in order to clarify this issue.

In addition, in this study we showed that IAPP probably does not have a classical hormone action, at least in patients with MTC, since it does not seem to affect insulin secretion from the pancreas, although there is evidence for such action at normal levels (23). Since we did not have the chance to examine plasma IAPP levels preoperatively, we cannot exclude the possibility that increased plasma IAPP levels might be a feature of metastatic disease.

Further studies will be needed to clarify this issue and to determine whether plasma IAPP could possibly serve as a marker of metastasis or aggravation of disease in MTC.

\section{References}

1 Marsh DJ, Learoyd DL \& Robinson BG. Medullary thyroid carcinoma: recent advances and management update. Thyroid 19955 407-424.

2 Wimalawansa SJ. Amylin, calcitonin gene-related peptide, calcitonin, and adrenomedullin: a peptide superfamily. Critical Reviews in Neurobiology 199711 167-239.

3 Morris HR, Panico M, Etienne T, Tippins JR, Girgis SI \& McIntyre I. Isolation and characterisation of human calcitonin gene related peptide. Nature $19843 \mathbf{3 0 8} 746-748$.

4 Edbrooke MR, Parker D, McVey JH, Riley JH, Sorensen GD, Pettengill OS et al. Expression of the human calcitonin/CGRP gene in lung and thyroid carcinoma. EMBO Journal 19854 715-724.

5 Williams ED, Ponder BJ \& Craig RK. Immunohistochemical study of calcitonin gene related peptide in human medullary carcinoma and c-cell hyperplasia. Clinical Endocrinology 198727 107-114.

6 Lasmoles F, Minvielle S, Cohen R, Guliana JM, Delehaye N, Segond $\mathrm{N}$ et al. PCR amplification of CGRPII mRNA. Variable expression in tumoral and non-tumoral human thyroid. FEBS Letters 1990277 243-246.

7 Schifter S. Expression of the calcitonin gene family in medullary thyroid carcinoma. Peptides 199718 307-317.

8 Alevizaki M, Dai K, Grigorakis SI, Legon S \& Souvatzoglou A. Amylin/IAPP expression in medullary carcinoma of the thyroid: correlation with the expression of the related calcitonin/CGRP genes. Clinical Endocrinology $1994 \mathbf{4 1} 21-26$.

9 Cooper GJS, Willis AC, Clark A, Turner RC, Simm RB \& Reid KBM. Purification and characterisation of a peptide from amyloid rich pancreas of type 2 diabetic patients. PNAS $1987 \mathbf{8 4} 8628-8632$.

10 Westermark P, Werstedt C, Wilander E, Hayden DW, O'Brien TD \& Johnson KA. Amyloid fibrils in human insulinoma and islets of Langerhans of the diabetic cat are derived from a neuropeptidelike protein also present in normal islet cells. PNAS $1987 \mathbf{8 4}$ 3881-3885. 
11 Hartter E, Svoboda T, Ludvik B, Schuller M, Lell B, Kuenburg E et al. Basal and stimulated plasma levels of pancreatic amylin indicate its co-secretion with insulin in humans. Diabetologia $19913452-54$.

12 Grigorakis SI, Alevizaki M, Rapti E, Anastasiou E, Alevizaki CC \& Souvatzoglou A. Islet amyloid polypeptide (amylin) does not seem to be directly involved in the development of gestational diabetes mellitus. Gynecologic and Obstetric Investigation 199744 6-10.

13 Holm R, Sobrinho-Simoes M, Nesland JM, Gould VE \& Johannessen JV. Medullary carcinoma of the thyroid gland: an immunocytochemical study. Ultrastructural Pathology $1985 \mathbf{8}$ 25-41.

14 Bretherton-Watt D, Ghatei MA, Bloom SE, Williams S \& Bloom SR. Islet amyloid polypeptide-like immunoreactivity in human tissue and endocrine tumors. Journal of Clinical Endocrinology and Metabolism $1993 \mathbf{7 6} 1072-1074$.

15 Stridsberg M, Eriksson B, Lundqvist G, Skogseid B, Wilander E \& Oberg K. Islet amyloid polypeptide (IAPP) in patients with neuroendocrine tumours. Regulatory Peptides 199555 119131.

16 VanHulst KL, Oosterwijk C, Born W, Vroom TM, Nieuwenhuis MG, Blankenstein MA et al. Islet amyloid polypeptide/amylin messenger RNA and protein expression in human insullinomas in relation to amyloid formation. European Journal of Endocrinology 1999140 69-78.

17 Ferrier GJM, Pierson AM, Jones PM, Bloom SR, Girgis SI \& Legon S. Expression of the rat amylin (IAPP/DAP) gene. Journal of Molecular Endocrinology 19893 R1-R4.
18 Nakagawa T, Mabry M, DeBustros A, Ihle JN, Nelkin BD \& Baylin SB. Introduction of $\mathrm{v}$-Ha-ras oncogene induces differentiation of cultured human medullary thyroid carcinoma cells. PNAS 198784 5923-5927.

19 Wang F, Adrian TE, Westermark GT, Ding X, Gasslander T \& Permert J. Islet amyloid polypeptide tonally inhibits beta-, alpha-, and delta-cell secretion in isolated rat pancreatic islets. American Journal of Physiology 1999276 E19-E24.

20 Care AD, Abbas SK, Pell J, Seitz PK \& Cooper CW. Stimulatory effect of insulin on calcitonin secretion. Hormone and Metabolic Research 199730 200-205.

21 Harris PJ, Cooper ME, Hiranyachattada S, Berka JL, Kelly DJ, Nobes $\mathrm{M}$ et al. Amylin stimulates proximal tubular sodium transport and cell proliferation in the rat kidney. American Journal of Physiology 1997272 F13-F21.

22 Cornish J, Callon KE, Cooper GJ \& Reid IR. Amylin stimulates osteoblast proliferation and increases mineralised bone volume in adult mice. Biochemical and Biophysical Research Communications 1995207 133-139.

23 Bennet WM, Beis CS, Ghatei MA, Byfield PGH \& Bloom SR. Amylin tonally regulates arginine-stimulated insulin secretion in rats. Diabetologia 199437 436-138.

Received 5 February 2001

Accepted 5 July 2001 